\title{
Road pricing versus tradable entry rights: a transaction cost approach
}

\author{
E. Crals \& L. Vereeck \\ Hasselt University, Belgium
}

\begin{abstract}
With respect to market-based transportation policies, it is a widely held view that road pricing entails substantial, though far fewer, transaction costs than tradable transportation permit systems. This conclusion seems to hold only if operational costs are singled out. This paper explores all relevant market, managerial and political transaction costs associated with road pricing and tradable entry rights. The two instruments have the same objective, namely to reduce congestion, and, to a lesser degree, noise, safety and environmental externalities. It is argued that the prevalence of transaction costs is largely dependent on the design of the policy instrument and the technology used. Developments in new technology will ensure that transaction costs associated with implementing a network wide, fleet wide road pricing or tradable entry permit system can remain at a low level. Comparative analysis further shows that a cap-and-trade program of entry permits distributed for free (on a smart card), traded on a brokered market and monitored downstream is not only more effective, but also likely to entail fewer transaction costs than road pricing. Any attempt, in turn, to save the huge information and search costs incurred by road pricing impairs its efficacy by severing the link between the externality and the price paid.
\end{abstract}

Keywords: road pricing, tradable permits, transaction costs.

\section{Introduction}

This paper examines how transport externalities can be internalized in an efficient and effective manner. New sustainable transport policies are therefore being developed. Economists [1] have long advocated road pricing as an efficient and equitable way to pay roadway costs, fund transportation programs, and encourage efficient transportation. However, while analysts see road pricing as 
an attractive policy tool, most attempts (e.g. the Netherlands) to introduce economic incentives of this type in the transport sector have failed. These failures may mostly be due to the fact that the public does not support these measures, but empirical research [2] also suggests that the inelasticity of the demand makes it difficult to introduce the appropriate price incentive.

Raux [3] focuses on the potential use of tradable permit systems in the transport sector and distinguishes two main criteria that can be used for judging their relevance. These are, on the one hand, the ability to impose a constraint or a right defined in a quantitative manner within a specified space-time, and, on the other hand, the ability that agents can transfer all or a portion of these quantitative obligations. The introduction of a tradable permit system in road transport typically serves two purposes, namely to effectively cap the global harm caused by road transport and, secondly, to efficiently internalize the social costs by setting the right price for a tradable right. The latter aim depends in turn on the number of participants, the transaction costs, hence the liquidity of the market [4]. One obstacle, indeed, would be the prevalence of prohibitively high transaction costs. When a market participant has substantial search and negotiation costs, it will lead to fewer transactions and, finally, undermine the functioning of the market. Moreover, prices will not accurately reflect marginal values. Specific attention will have to be paid to setting up a transparent, atomistic market. Alternatively, the efficiency of the market also depends on the administrative costs of the system which increase with the number of participants.

However, does road pricing really entail fewer transaction costs than tradable entry permits (TEP) or are the costs of both systems prohibitively high which explains their limited use? In order to compare instruments that have the same incentives, we will pursue a transaction cost analysis for both road pricing and TEP. The main objective of these instruments is to reduce congestion. We have already extensively discussed in a previous paper the design and goal of TEP [5]. Design, implementation and economics of road pricing schemes are also discussed in depth in literature (e.g. [6] and [7]). Consequently, we will not elaborate further on the design issues of both policy instruments.

This paper is organized as follows. Section 2 presents briefly the theory of tradable permits in externalities and defines the relevant transaction costs leading to the implementation of a road pricing measure. Section 3 presents a comparative transaction cost analysis of road pricing and TEP while section 4 concludes with some final thoughts on the policy implications of this research.

\section{Theory of tradable permits and transaction costs}

This paper analyzes two policy approaches dealing with negative externalities: road pricing (variable taxes) and tradable permits. Both are market-based instruments that use the price system to internalize spill-over effects. In theory, market-based instruments compare favourably to regulation because they are flexible and cost-effective as formally demonstrated by Baumol and Oates [8]. The intellectual roots of tradable permits can be traced back to a seminal article by Coase [9] and the concept was readily put into practice by the US 
Environmental Protection Agency (EPA) which started to use permit trading as an instrument to control air emissions. The concept of tradable permits really rose to prominence though after the Kyoto Protocol which calls for international emissions' trading (Kyoto Protocol, article 17).

Basically, there exist four types of tradable permit systems: a credit, cap-andtrade, averaging and usage rights system. Since the latter two have only limited application, only the former will be briefly discussed. A credit program imposes a constraint on each individual participant. Transferable reduction credits can then be gained by creating fewer externalities than the legal limit which is derived from existing regulation or determined by expected future externalities. In a cap-and-trade system, however, the regulatory authority determines the total acceptable amount of externalities (cap) and, subsequently, distributes fully tradable permits among participants. Whatever the distribution method (free, grandfathering, updating or auctioning), the sum of those tradable rights adds up to the cap. Despite their apparent similarity, Tietenberg [10] has argued that there are substantial differences between both approaches. A cap-and-trade system is more effective because the cap is a physical limit on externalities. Since the number of permits is limited accordingly, external cost increases can only be compensated by reductions elsewhere. That way, by definition, policy targets are always met. Cap-and-trade is also flexible because the regulatory authority can set the cap at its discretion. Dynamic efficiency is obtained because cap-andtrade provides clear incentives to reduce externalities. Since excess permits can be sold, exemplary participants are directly rewarded. Finally, tradability assures that the permits end up where they yield their highest value. In other words, regardless of the initial distribution, trade will result in an efficient allocation of permits equalizing marginal costs among participants.

Transaction costs are helpful in explaining institutional phenomena. They have entered different field of mainstream economics like organization theory, welfare economics and public choice. Overall, transaction cost economics has clearly contributed to the understanding of observed patterns of organization [11]. We already discussed the theory of transaction costs in depth in a previous paper [12]. Here, we will briefly summarize the results by providing comprehensive a classification of transaction costs which will be used in this analysis. More specifically, in running a transport pricing policy, the corresponding activities are likely to entail the following market, organizational and political transaction costs:

- Legislative costs which includes lobbying costs, public support costs and legal barrier costs;

- Information costs about external costs;

- $\quad$ Search (planning) costs for the appropriate design of the system;

- Operational costs including technology costs;

- Negotiation costs between car users or between the government and car users;

- Contract costs with other car users;

- Monitoring and enforcement costs; and

- Compliance costs. 
Without indiscrimination, public policies give rise to substantial transaction costs. Therefore, a comparative approach is required to assess the cost efficiency of a specific program. The assessment of the same cost categories sets off a common criticism that the analysis is incomplete or that different definitions make any comparison virtually impossible [13].

\section{Comparative transaction cost analysis}

One of the major challenges in designing transport pricing systems is how best to reduce implementation and transaction costs. Transaction costs can occur for several reasons as a result of which the optimization problem of a participant who wants to trade in permits will change. As stated by Stavins [14], the effect of transaction costs is "unambiguously to decrease the volume of permit trading regardless of the specific forms that the marginal control cost functions and transaction costs function take". Furthermore, the large number of users in the transport sector constitutes an obvious obstacle to introduce tradable permit systems, since negotiation costs appear, a priori, to be prohibitive. We shall examine this question by discussing all relevant transaction costs associated with road pricing and TEP.

\subsection{Legislative costs}

The first step in the realization of a new policy program is to secure sufficient support from the legislator. This gives rise to legislative costs which comprise the costs of lobbying politicians (and bureaucrats) and enacting legislation. These costs will be high for both systems because public opinion needs a lot of convincing and political support which is running low, and needs to be created. Much depends on the design of the system though and the use of the revenues. However, legislative costs are not a good criterion to reject or accept one of the systems because in both cases, lobbying for or con the program will take place. More specifically, lobbying against the introduction of one system can be easily interpreted as rent-seeking in favour of the other.

\subsection{Information costs}

In order to internalize external effects, the road charge on the individual user should be related to the marginal costs imposed on the rest of society - highest in congested conditions, lower in uncongested conditions but still calculated to cover pollution, noise, accident and road repair costs. Efficient use of road space therefore requires a highly differentiated tariff which will induce substantial information costs. More specifically, congestion costs must be quantified before road pricing can be implemented. The social costs of congestion can be measured by the deadweight loss and calculated from the difference between the marginal social costs and the price actually paid by trip makers.

In a system of tradable permits however, no information is needed about price elasticity or abatement costs. The regulating authority only needs to set the height of the cap, which is the capacity of the roads. After establishing this cap, 
prices will adapt automatically to changing circumstances. The design of the program may also be a source of data collecting costs. However, the initial distribution method does not affect the efficacy of the instrument and therefore, compared to road pricing, information costs are negligible.

\subsection{Search (planning) costs}

A flat fee for road users does not provide the right incentive which properly represents the true social costs. An optimal road pricing scheme requires linking the road charge to the external effects. However, the relationship between a cause and its effect can be a very complicated function, with thresholds, feedback relations, time lags and so on. These difficulties are also reflected in any attempt to monetize the external effect. For the valuation, a broad range of techniques have been developed over the last decades. Examples are behavioural approaches such as hedonic techniques, travel cost methods, production factor methods and contingent valuation methods and non-behavioural approaches such as damage costs, costs of illness and prevention costs. From a theoretical point of view, behavioural techniques deserve preference, as they aim to assess the individuals' valuation of the effect. However, monetization costs are much higher when undertaking valuation studies. To conclude, there exists a trade-off between search costs on the one hand, and the optimality of the road pricing instrument on the other. Furthermore, search and planning costs are even higher when behavioural techniques are used to valuate the various external effects.

Search costs of a TEP system are dependent on the design of the program. Allocating permits to individuals is attractive primarily because it provides a direct incentive to reduce fuel consumption or vehicle use through choice of vehicle, patterns of travel behaviour (including mode choice) and residential location. However, allocating permits downstream is often criticized because of substantial planning costs. These planning costs are, for example, a centralized electronic system that is needed to handle a large number of transactions and a large scale public education campaign. Allocating permits upstream, at the level of fuel wholesalers or producers, induces low planning costs but is not applicable to TEP.

\subsection{Set-up costs}

Traditional ways of collecting tolls (e.g. tollbooths in France) have high set-up costs and can impose long waiting periods for drivers. But with the introduction of electronic tolling and other technologies, there are no significant technical barriers to more direct and efficient charges for road use. For example, in-vehicle meters which record the travel characteristics of the vehicle can be used for congestion-based, time-based or distance-based charging [15]. Consequently, potentially the biggest cost involved in setting-up a charging scheme would be the cost of establishing a vehicle fleet with the necessary equipment on-board. In general, the set-up costs vary with the type of technology and with the size of the scheme in question. However, due to the latest developments, technology is no longer a barrier for the introduction of road pricing. The scheme also needs to be 
set-up administratively. The key issues involved here are the costs of telecommunication between on-board units and back-office and the costs of setting up the back-office processing operation. If the road tolls can be levied and collected by an established agency, set-up costs are of course smaller than when a whole new back-office needs to be set up.

The extent of the set-up costs in case of TEP is dependent on the distribution system chosen. Because TEP make use of auctioning and free distribution, set-up costs will be high. Data will have to be collected to determine the quota which individuals will receive for free. In addition, the urban authority has to set up a yearly auction. Organization set-up costs are also dependent on the technology used. Permits can be put on so-called smart cards which are installed in the vehicle and used in conjunction with an in-lane camera/reader to communicate identifying information about the vehicle, customer, and account balance information of the non-complier.

\subsection{Operational costs}

The operating costs of a road pricing scheme can be substantial, depending on the technology used. Registering drivers for any scheme, processing records of vehicle movements into charges, and issuing these charges as bills to drivers requires a significant back-up operation and, in case of a large number of vehicles, significant costs (e.g. cameras). Operating costs will rise in accordance with the complexity of the road charging scheme. However, in cases of synergies with existing vehicle and driver services, additional costs of road charging schemes could be reduced considerably if these synergies are exploited properly.

In the case of TEP, few requirements, approval processes and well defined entry rights are necessary to keep operational costs minimal. In general, bureaucratic interference should be kept as low as possible because this can obstruct the system and entail substantial operational costs. Citizens need the freedom to decide themselves who to trade with and how to comply with the cap. In conclusion, operational costs will be kept low in comparison with those of road pricing systems if permits holders are able to sell their excess permits with as little regulatory interference as possible.

\subsection{Negotiation costs}

As road pricing refers to charging for the direct use of the road and because the system is compulsory, car drivers will be directly affected by the scheme. The price is determined by the internalization of external effects and it is assumed that no negotiation between the regulating authority and road users takes place. However, road users can negotiate among themselves in order to minimize costs (e.g. carpooling). Negotiation costs will then incur between affected parties. Nevertheless, negotiation costs are assumed to be relatively small.

Negotiation costs in a TEP system occur because of bargaining between citizens or between the government and individuals. However, institutions and different market structures can be set up to facilitate the trade of permits such as direct search markets, brokered markets, dealer markets and auction market. If an 
electronic market emerges, negotiation costs will be further reduced. Once a party has found another party to trade, bargaining will start. When information on prices is publicly available, this bargaining process will be standardized. When citizens are confronted with substantial search costs, fewer transactions will occur and hence the functioning of the market will be undermined. Ultimately, negotiation costs will be minimized by a transparent market, the use of market intermediaries, minimal complexity of government regulation and clarity of property rights.

\subsection{Contract costs}

The costs of contracting for both regimes are zero because of a spot transaction without time lapse between the promise and actual transfer in case of an entry rights, and between paying the road charge and the actual use of the road in case of road pricing.

\subsection{Monitoring and enforcement costs}

The greater the complexity of any road charging scheme, the greater the specificity of data that need to be gathered about road use and the greater the enforcement costs. Furthermore, the greater the extent to which enforcement is pursued, the lower the marginal returns. In most circumstances, enforcement authorities will be faced with decisions about how far to pursue cases in which there is little prospect of recovering the cost of enforcement, although to do so will increase the deterrent effect. Consequently, there exists a trade-off between evasion rate, enforcement costs and the likelihood of detection. Technology plays also an important role in enforcement. If cameras are used to detect vehicles which are evading the charge, enforcement costs will be high because of the high number of cameras needed. If electronic vehicle identification (EVI) is used which involves setting a device in vehicles, enforcement costs could be significantly reduced.

Adequate monitoring and enforcement is vital to the success of any tradable permit scheme. There are, however, significant differences in the cost and difficulty of these tasks, depending on how the permit scheme operates. Downstream monitoring, as in the case of TEP, involves many market players and thus higher costs. If a vehicle does not dispose of a working on-board unit or if the credit on the smart card is insufficient, an image of the number plate will be made. Using automatic number plate recognition (ANPR), this number plate will be identified and the vehicle owner is obliged to pay a fine. Consequently, the technology used comprises number plate recognition and CCTV (Closed Circuit TeleVision) camera observation at the entrance gates. Furthermore, monitoring and enforcement costs depend on the fact if a TEP system can fit in with existing institutions for levying taxes. If these administrations are already up and running, monitoring and enforcement costs can be reduced. 


\subsection{Compliance costs}

Road users incur costs to comply with any transport pricing scheme. In order to minimize these costs, every scheme will need to reflect the following strategies:

- Ease of use: charge payers must have easy access to the means of registration and payment;

- Ease of understanding: charge payers must know exactly what is expected of them;

- Customer service; and

- Social inclusion: to be achieved through ensuring the widest range of methods of payment.

The primary source of compliance costs for road users involve taxpayers' loss of time, namely the amount of time that road users are delayed by buying permits or paying the road charge. The compliance costs will be minimized when buying and selling permits or paying the road price can be done electronically. Consequently, compliance costs decrease in both systems on account of applied technology which uses electronic payment methods [16].

\section{Conclusion}

Comparison between tradable permits and equivalent taxes are normally based on standard analysis that assumes absence of transaction costs. As Stavins [14] shows, the existence of transaction costs introduces ambiguities into the choice between permits and other policy instruments, 'the supposed symmetry of taxes and permits becomes questionable, and the need to compare these instruments on a case-by-case basis becomes more compelling'. Unfortunately, there is no a priori method of choosing between taxes and tradable permits. In case of road pricing, a flat fee will induce far fewer transaction costs than differentiated prices, but will also not be very effective. Therefore, in table 1, a comparative transaction cost analysis is performed of effective road pricing and TEP measures (inducing the appropriate price incentives).

Table 1 reveals that, from a transaction cost perspective, the effective TEP system is a downstream operation in which the urban authority distributes the permits (on a smart card) for free and ensures that excess permits can be sold via an electronic market. The table also shows that effective road pricing entails higher fixed costs, namely information, search and set-up costs, than an effective tradable entry permit system.

However, the choice between TEP and road pricing can only be made when case-specific factors are taken into account. Which instrument is best, depends upon a variety of characteristics of the environmental problem: social legitimacy, political feasibility, economic impact and regulatory context. Furthermore, transaction costs are historical costs. What are prohibitively high costs today need not be prohibitive tomorrow. So, transaction cost analysis needs to be complemented by cost-benefit or cost-effectiveness studies. By further quantitative research, additional information can be gathered on the 
administrative requirements of permit trading systems and the changes in relevant institutional structures that are necessary to introduce policy instruments with low transaction costs. The theoretical transaction cost approach presented here can serve as a starting point for such studies.

Table 1: $\quad$ Transaction costs of effective transport policy instruments.

\begin{tabular}{|c|c|c|c|}
\hline $\begin{array}{l}\text { Transaction } \\
\text { costs }\end{array}$ & $\begin{array}{l}\text { Fixed/ } \\
\text { Variable }\end{array}$ & Road pricing & TEP \\
\hline Lobbying costs & Fixed & $\begin{array}{l}\text { High (lobbying of all } \\
\text { affected parties) }\end{array}$ & $\begin{array}{l}\text { High (free distribution, } \\
\text { auctioning) }\end{array}$ \\
\hline $\begin{array}{l}\text { Information } \\
\text { costs }\end{array}$ & Fixed & $\begin{array}{l}\text { Very High } \\
\text { (internalization external } \\
\text { costs, variable road } \\
\text { charge) }\end{array}$ & $\begin{array}{l}\text { Very low (cap, free } \\
\text { distribution, auctioning) }\end{array}$ \\
\hline $\begin{array}{l}\text { Public support } \\
\text { costs }\end{array}$ & Fixed & $\begin{array}{l}\text { Low (providing } \\
\text { alternatives and } \\
\text { addressing equity issues) }\end{array}$ & Low (free distribution) \\
\hline $\begin{array}{l}\text { Search } \\
\text { (planning) costs }\end{array}$ & Fixed & $\begin{array}{l}\text { Very high (differential } \\
\text { road charge) }\end{array}$ & $\begin{array}{l}\text { High (allocating permits to } \\
\text { individuals) }\end{array}$ \\
\hline Set-up costs & Fixed & $\begin{array}{l}\text { Average (automatic } \\
\text { vehicle identification) }\end{array}$ & Low (smart cards) \\
\hline $\begin{array}{l}\text { Operational } \\
\text { costs }\end{array}$ & Variable & $\begin{array}{l}\text { High (registration of } \\
\text { drivers + camera } \\
\text { technology) }\end{array}$ & $\begin{array}{l}\text { Low (few requirements and } \\
\text { no approval processes) }\end{array}$ \\
\hline $\begin{array}{l}\text { Negotiation } \\
\text { costs }\end{array}$ & Fixed & $\begin{array}{l}\text { Very low (no } \\
\text { negotiation) }\end{array}$ & $\begin{array}{l}\text { Very low (auction, } \\
\text { electronic market) }\end{array}$ \\
\hline Contract costs & Fixed & Zero (spot transaction) & Zero (spot transaction) \\
\hline $\begin{array}{l}\text { Monitoring and } \\
\text { enforcement } \\
\text { costs }\end{array}$ & Variable & Average (EVI) & $\begin{array}{l}\text { High (downstream, } \\
\text { cameras) }\end{array}$ \\
\hline $\begin{array}{l}\text { Compliance } \\
\text { costs }\end{array}$ & Variable & $\begin{array}{l}\text { Low (electronic } \\
\text { payments) }\end{array}$ & Low (technology) \\
\hline Total Costs & & $\begin{array}{l}\text { High fixed costs of } \\
\text { effective road pricing, } \\
\text { average variable costs }\end{array}$ & $\begin{array}{l}\text { Average fixed costs, low } \\
\text { variable costs, but high } \\
\text { monitoring and } \\
\text { enforcement costs }\end{array}$ \\
\hline
\end{tabular}

\section{References}

[1] Button, K.J. \& Verhoef, E.T. (eds.), Road Pricing, Traffic Congestion and the Environment: Issues of Efficiency and Social Feasibility, Edward Elgar: Cheltenham, 1998.

[2] Graham, D. \& Glaister, S., The Demand for Automobile Fuel: A Survey of Elasticities. Journal of Transport Economics and Policy, 36, pp. 1-26, 2002.

[3] Raux, N., The Use of Transferable Permits in the Transport Sector. Implementing Domestic Tradable Permits: Recent Developments and Future Challenges. ed. OECD, Paris: OECD, pp. 141-182, 2002. 
[4] Noll, R.S., The Feasibility of Marketable Emission Permits in the United States, Social Science Working Paper 397, Pasadena: California Institute of Technology, 1981.

[5] Crals, E. \& Vereeck, L., A More Sustainable Urban Transport System: The Case of Tradable Entry Permits. Urban Transport XI. eds. C.A. Brebbia \& Wadhwa, L.C., WIT Press: Southampton, pp. 301-312, 2005.

[6] Verhoef, E., The Economics of Regulating Road Transport, Edward Elgar: Cheltenham, 1996.

[7] Button, K., Road Pricing as an Instrument in Traffic Management. Road Pricing: Theory, Empirical Assessment and Policy. eds. B. Johansson \& Mattsson, L.-G., Kluwer Academic Publishers: Dordrecht, pp. 35-55, 1995.

[8] Baumol, W.J. \& Oates, W.E., The Use of Standards and Prices for Protection of the Environment. Swedish Journal of Economics, 73, pp. 4254, 1971.

[9] Coase, R.H., The Problem of Social cost. Journal of Law and Economics, 3, pp. 1-44, 1960.

[10] Tietenberg, T., The Tradable Permits Approach to Protecting the Commons: What have We Learned? The Drama of the Commons. eds. E. Ostrom et al., National Academy Press: Washington, pp. 197-232, 2001.

[11] Rao, P.K., The Economics of Transaction Costs: Theory, Methods and Applications, Palgrave Macmillan: New York, 2003.

[12] Crals, E. \& Vereeck, L., Taxes, Tradable Rights and Transaction Costs. European Journal of Law and Economics, 20(2), pp. 199-223, 2005.

[13] Woerdman, E., Emissions Trading and Transaction Costs: Analyzing the Flaws in the Discussion. Ecological Economics, 38, pp. 293-304, 2001.

[14] Stavins, R., Transaction costs and tradeable permits. Journal of Environmental Economics and Management, 29(2), pp. 133-148, 1995.

[15] Santos, G., On the Economic, Technological and Political Aspects of Road Pricing as a Tool for Traffic Demand Management. Proc. of the European Transport Conference, Homerton College: Cambridge, September 11-13, 2000

[16] Kaplow, L., How Tax Complexity and Enforcement Affect the Equity and Efficiency of the Income Tax. National Tax Journal, 49(1), pp. 135-150, 1996. 